\title{
Distribution of cold-water corals in the Whittard Canyon, NE Atlantic Ocean
}

\author{
Kirsty J. Morris ${ }^{\mathrm{a}, *}$, Paul A. Tyler ${ }^{\mathrm{a}}$, Doug G. Masson ${ }^{\mathrm{b}}$, Veerle I.A. Huvenne ${ }^{\mathrm{b}}$, Alex D. Rogers ${ }^{\mathrm{c}}$ \\ a Ocean and Earth Science, University of Southampton, Waterfront Campus, Southampton SO14 3ZH, UK \\ ${ }^{\mathrm{b}}$ Natural Environment Research Council, National Oceanography Centre Southampton, European Way, Southampton SO14 3ZH, UK

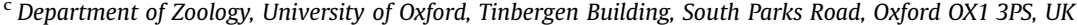

\section{A R T I C L E I N F O}

\section{Available online 24 March 2013}

Keywords:

ROV video analysis

Octocorals

Benthic ecology

Continental slope

Submarine canyon

\begin{abstract}
A B S T R A C T
The deep-sea floor occupies about $60 \%$ of the surface of the planet and is covered mainly by fine sediments. Most studies of deep-sea benthic fauna therefore have concentrated on soft sediments with little sampling of hard substrata, such as rocky outcrops in submarine canyons. Here we assess the distribution and abundance of cold-water corals within the Whittard Canyon (NE Atlantic) using video footage from the ROV Isis. Abundances per $100 \mathrm{~m}$ of video transect were calculated and mapped using ArcGIS. The data were separated into five substratum types, 'Sediment', 'Mixed Sediment and Rock', 'Sediment Slope', 'Lophelia reef and 'Lophelia and rock'. Abundance and community structure were compared. A maximum abundance of 855 coral colonies per $100 \mathrm{~m}$ of ROV transect were observed with 31 coral types identified. Highest taxon richness was observed along a 'Lophelia reef' area, although a larger richness of Octocorallia was observed away from the 'Lophelia reef' areas. 'Lophelia reef and 'Lophelia and rock' areas were found to have a different coral community structure from the other substratum types. We suggest this is the result of Lophelia outcompeting other coral types because there is increased coral taxon richness in areas without Lophelia. We also hypothesise that the hydrodynamic regime within the Whittard Canyon results in differences in organic matter input including higher quality food, in comparison with other deep-water environments, leading to changes in the coral communities.
\end{abstract}

Crown Copyright $\odot 2013$ Published by Elsevier Ltd. All rights reserved.

\section{Introduction}

Corals are best known from shallow tropical seas, despite $>65 \%$ of recorded coral species occurring below $50 \mathrm{~m}$ depth (Cairns, 2007; Lindner et al., 2008; Roberts et al., 2009). In contrast to their shallow-water counterparts, cold-water corals do not require light or high temperatures to survive in deep-waters because they do not have a symbiotic relationship with zooxanthellae (algae). They are exclusively filter feeders. The morphology of many cold-water corals allows them to contribute structural complexity to deep-sea ecosystems (Watanabe et al., 2009) and to provide a habitat for a wide variety of different taxa (BuhlMortensen and Mortensen, 2005; Clark et al., 2006). Recognition that these ecosystems make a potentially significant contribution to deep-sea biodiversity means there is a requirement for better understanding of the distribution of coral habitats in the deep ocean, including in submarine canyons, in order to improve the management of these ecosystems.

\footnotetext{
* Corresponding author. Tel.: +442380596333.

E-mail address: k.morris@noc.ac.uk (K.J. Morris).
}

Submarine canyons are steep-sided valleys that cut across continental margins. They are common on many continental shelf edges and slopes (de Stigter et al., 2007; de Leo et al., 2010; Harris and Whiteway, 2011). Canyons exhibit a range of morphologies from relatively shallow systems with many gullies to deeply incised sinuous valleys (Harris and Whiteway, 2011). The flow of water in canyons is governed by the surrounding topography and the physical environment, which differs from the continental slope (Genin et al., 1986; Davies et al., 2008). Current velocities increase when flow comes into contact with steep topography (Genin et al., 1986, 1989). In a canyon this can be coupled with the creation of higher intensity internal waves than the surrounding slopes (Quaresma et al., 2007). This can result in increased turbulence and sediment resuspension, leading to the creation of nepheloid layers and turbidity flows within the canyon (de Stigter et al., 2007; Arzola et al., 2008). The combination of these phenomena make canyons significant for shelf-slope particulate exchange (Oliveria et al., 2002; Quaresma et al., 2007; Arzola et al., 2008; Garcia et al., 2008). Consequently, canyons are highly heterogeneous environments leading to the creation of a wide variety of niches for biological communities. The amalgamation of these 
factors means canyons are often thought of as areas of enhanced biodiversity (de Leo et al., 2010; Vetter et al., 2010). However, very little work has occurred on the biological assemblages and their community structure within canyons, especially cold-water coral assemblages (Huvenne et al., 2011). The present study seeks to increase knowledge on the distribution of deep-sea corals within submarine canyons, focussing on the Whittard Canyon system on the continental margin in the NE Atlantic.

The Whittard Canyon is located to the south east of the Goban Spur (NE Atlantic), along the continental margin in the northern Bay of Biscay around $300 \mathrm{~km}$ south of Ireland (Fig. 1). Water masses in the North Eastern Atlantic have been described by Vangrieshem (1985) and Arhan et al. (1994). Aminot and Kerouel (2004) summarised the water masses as North Atlantic Surface Water (max $100 \mathrm{~m}$ depth) overlying Eastern North Atlantic Central Water $($ ENACW) $(<700 \mathrm{~m})$. A steep pycnocline separates the ENACW from Mediterranean Outflow Water (MOW). The MOW extends down to about $1200 \mathrm{~m}$, mixing with the underlying Labrador Sea Water marked by a salinity minimum at around $1800 \mathrm{~m}$. There is some influence of Norwegian Sea Water at around $2000 \mathrm{~m}$. Below this depth North Atlantic Deep Water (NADW) derived from Greenland appears, and is heavily influenced by the pervading Atlantic Antarctic Bottom Water at greater depths (Matthias and Godfrey, 2003; Aminot and Kerouel, 2004; De Mol et al., 2011).

The Whittard Canyon extends from the upper slope to abyssal depths, varying in depth between 200 and $4000 \mathrm{~m}$ (Duineveld et al., 2001), with two main branches (Fig. 1). These run from the shelf edge down into the canyon and at approximately $3700 \mathrm{~m}$ depth merge into one large channel which opens out onto the Porcupine Abyssal Plain. The canyon floor is sediment-covered with very little exposed rock, other than on the extreme walls (Reid and Hamilton, 1990). Duineveld et al. (2001) found that the POC concentrations were higher in the canyon than in the surrounding open slope areas, indicating organic enrichment

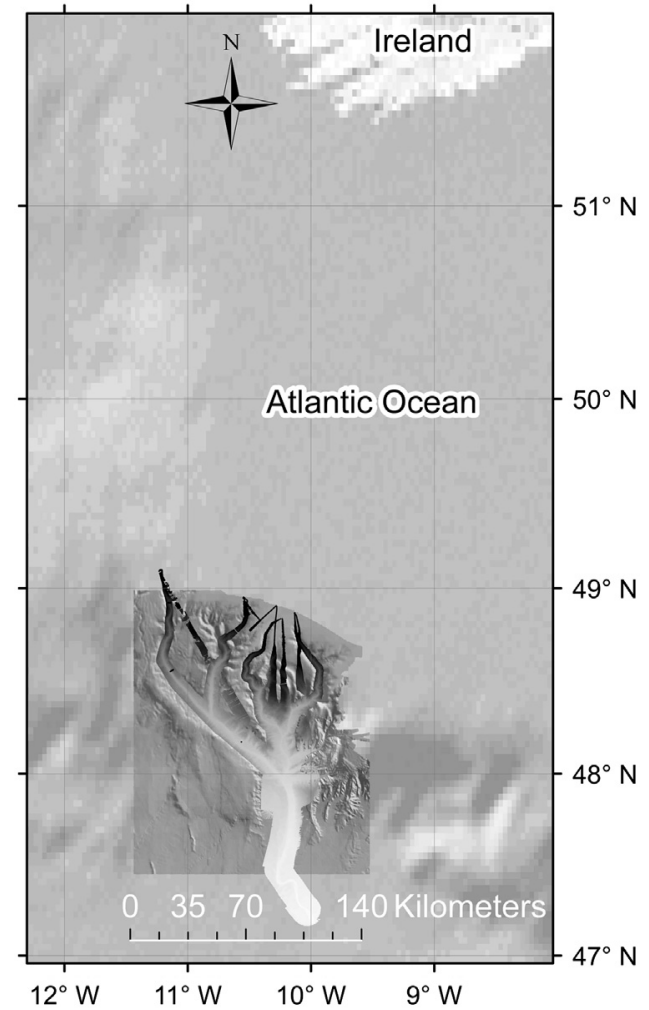

Fig. 1. Location of Whittard Canyon on the Celtic margin, Bay of Biscay. within the canyon. The surface waters of the upper reaches of the canyon have relatively high biological productivity because of nutrient upwelling along the Celtic Shelf edge (Wall et al., 2010), resulting in increased nutrient transport through the canyon via mechanisms such as internal wave formation and turbidity flows.

The main aim of our research was to describe the abundance, distribution and community composition of cold-water corals in the Whittard Canyon in relation to substratum type. The study was based on video and photographic observations taken from the Remotely Operated Vehicle (ROV) Isis.

\section{Materials and methods}

\subsection{Data collection}

Observations of the seabed were taken with video and stills imagery using the ROV Isis during RRS James Cook cruises 10 and 36 (JC10 and JC36) to the Whittard Canyon (Weaver and Masson, 2007; Masson, 2009). A total of 13 dives with extensive video transects were completed resulting in over 80 hours of video. Transects were obtained mainly in the major branches of the canyon, the easternmost and westernmost tributaries (Fig. 2). The flanks of the canyon were studied over a range of depths between 520 and $4073 \mathrm{~m}$ (Table 1).

Isis was fitted with multiple cameras, which were used for piloting the vehicle and for scientific observations. The scientific cameras were a fixed Atlas 3-chip camera with a $14 \times$ optical zoom and a Pegasus pan and tilt camera, which both record onto DVCAM tapes and DVD, and a Scorpio 3.34 mega-pixel digital still colour camera. In order to obtain video footage, the sea floor was illuminated by two $600 \mathrm{~J}$ strobe lamps, five $250 \mathrm{~W}$ incandescent lamps and three HMI $1200 \mathrm{~W}$ lamps.

\subsection{Video analysis}

The video footage was analysed using the computer package U-lead Video, version 10 . Each video was analysed in its entirety with the occurrence of individual coral colonies being noted along the transect with the time, depth and substratum type. The seabed observed within the video footage indicates the Whittard Canyon is dominated by sediment (mud and sand) and sediment-draped rocks. Two dives provided footage of Lophelia reefs on steep overhangs. In some cases, the Lophelia had been covered in sediment and subsequently had perished. However, this led to a novel substratum colonised by octocorals, the focus of this study. A distinction was made therefore between live 'Lophelia reef and 'Lophelia and rock' where reefs were not created (Fig. 3). Five different substratum types were identified in the Whittard Canyon; 'Sediment', 'Sediment Slope', 'Mixed Sediment and Rock', 'Lophelia reef and 'Lophelia and rock' (Fig. 3).

Although laser scales are used in conjunction with video on Isis, it was not always possible to view where they mark the seabed, due to changes in ROV altitude, making the area of the field of view hard to determine. Therefore it was decided to analyse the images in terms of time rather than area, making the assumption that during transects Isis travelled at a speed of $\sim 0.1$ knots $\left(5 \mathrm{~cm} \mathrm{~s}^{-1}\right)$. For each dive a $50 \mathrm{~min}$ concatenated segment of the parameter being analysed i.e. depth or substratum type (Supplementary Tables 1 and 2) was used to allow a consistent method for comparison between dives of differing lengths as well as ensuring a manageable data set was achieved. These 50-minute concatenated segments consisted of ten continuous 5 min segments randomly chosen per dive. Where it was not possible to obtain these data the dive was not included in the analysis. This resulted 




\section{Depth (m)}



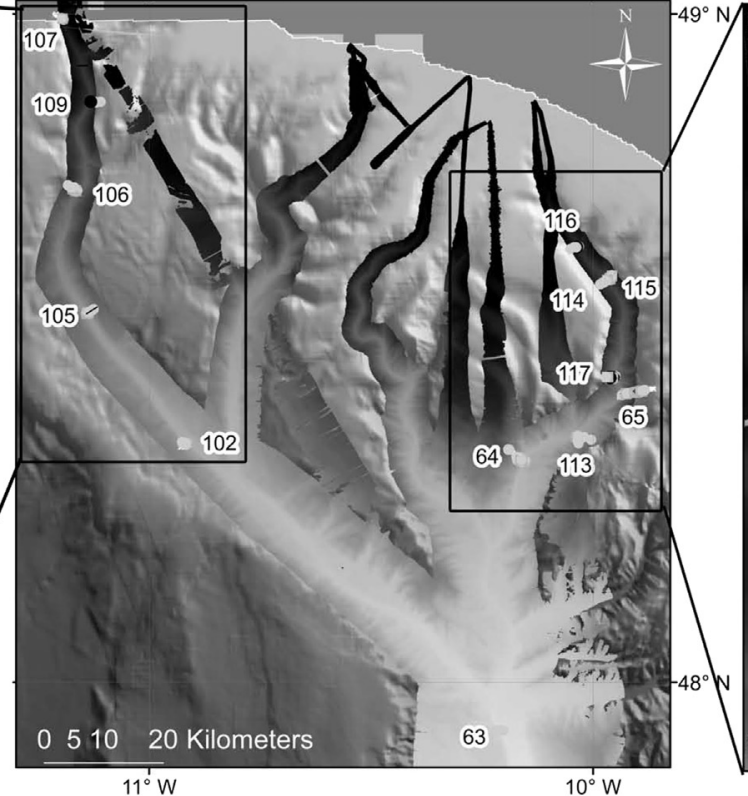

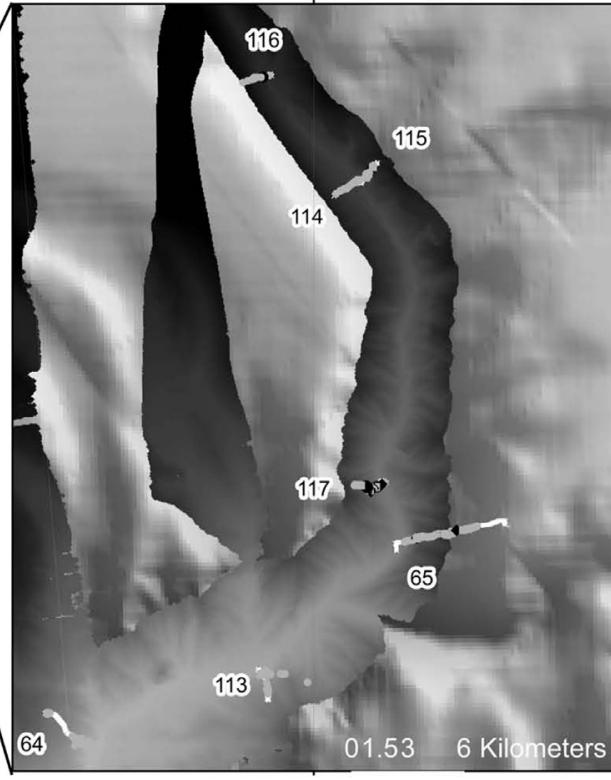

Abundance of corals per $100 \mathrm{~m}$ transect

$$
\begin{array}{ll} 
& 1-19 \\
=\quad & 19-56 \\
+\quad & 56-149 \\
+\quad & 149-233 \\
-\quad & 233-855
\end{array}
$$

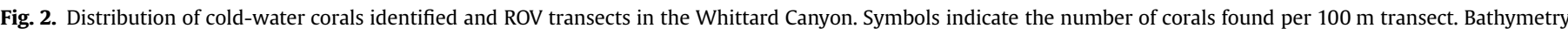

\begin{tabular}{|c|c|c|c|c|c|c|c|c|}
\hline Isis (dive no) & Date & Start longitude (W) & Start latitude (N) & End longitude (W) & End latitude (N) & Depth range (m) & Hours video & Length transect (m) \\
\hline 63 & 03/07/2007 & $10^{\circ} 12.09^{\prime}$ & $48^{\circ} 55.75^{\prime}$ & $10^{\circ} 13.31^{\prime}$ & $47^{\circ} 55.45^{\prime}$ & $3706-4073$ & 6.5 & 1810 \\
\hline 64 & $04 / 07 / 2007$ & $10^{\circ} 9.200^{\prime}$ & $48^{\circ} 19.94^{\prime}$ & $10^{\circ} 11.48^{\prime}$ & $48^{\circ} 21.04^{\prime}$ & $2157-3455$ & 9.5 & 3822 \\
\hline 65 & $04 / 07 / 2007$ & $10^{\circ} 11.49^{\prime}$ & $48^{\circ} 21.04^{\prime}$ & $09^{\circ} 51.62^{\prime}$ & $48^{\circ} 26.39^{\prime}$ & $520-2641$ & 14.5 & 6875 \\
\hline 102 & $25 / 06 / 2010$ & $10^{\circ} 54.48^{\prime}$ & $48^{\circ} 21.87^{\prime}$ & $10^{\circ} 55.64^{\prime}$ & $48^{\circ} 21.18^{\prime}$ & $2578-3163$ & 7.5 & 2485 \\
\hline 105 & $28 / 06 / 2010$ & $11^{\circ} 08.44^{\prime}$ & $48^{\circ} 33.26^{\prime}$ & $11^{\circ} 07.40^{\prime}$ & $48^{\circ} 33.67^{\prime}$ & $2840-3085$ & 7 & 1905 \\
\hline 106 & $29 / 06 / 2010$ & $11^{\circ} 09.48^{\prime}$ & $48^{\circ} 44.01^{\prime}$ & $11^{\circ} 11.04^{\prime}$ & $48^{\circ} 44.77^{\prime}$ & $1640-2300$ & 7 & 2501 \\
\hline 107 & $30 / 06 / 2010$ & $11^{\circ} 11.36^{\prime}$ & $48^{\circ} 59.38^{\prime}$ & $11^{\circ} 12.14^{\prime}$ & $48^{\circ} 59.80^{\prime}$ & $600-1062$ & 12 & 2751 \\
\hline 109 & $01 / 07 / 2010$ & $11^{\circ} 08.16^{\prime}$ & $48^{\circ} 52.22^{\prime}$ & $11^{\circ} 08.22^{\prime}$ & $48^{\circ} 52.31^{\prime}$ & $958-1727$ & 8.5 & 2539 \\
\hline 113 & $13 / 07 / 2010$ & $10^{\circ} 02.37^{\prime}$ & $48^{\circ} 22.29^{\prime}$ & $10^{\circ} 01.95^{\prime}$ & $48^{\circ} 21.47^{\prime}$ & $2395-3202$ & 9 & 2010 \\
\hline 114 & $18 / 07 / 2010$ & $09^{\circ} 58.00^{\prime}$ & $48^{\circ} 36.19^{\prime}$ & $09^{\circ} 57.28^{\prime}$ & $48^{\circ} 36.75^{\prime}$ & $1102-1640$ & 11.5 & 1704 \\
\hline 115 & 19/07/2010 & $09^{\circ} 58.07^{\prime}$ & $48^{\circ} 36.28^{\prime}$ & $09^{\circ} 59.08^{\prime}$ & $48^{\circ} 35.85^{\prime}$ & $1378-1677$ & 6 & 1876 \\
\hline 116 & 19/07/2010 & $10^{\circ} 01.85^{\prime}$ & $48^{\circ} 39.29^{\prime}$ & $10^{\circ} 03.05^{\prime}$ & $48^{\circ} 39.04^{\prime}$ & $892-1370$ & 9 & 1707 \\
\hline 117 & $20 / 07 / 2010$ & $09^{\circ} 56.97^{\prime}$ & $48^{\circ} 27.65^{\prime}$ & $09^{\circ} 58.20^{\prime}$ & $48^{\circ} 27.60^{\prime}$ & $1672-2448$ & 11 & 1999 \\
\hline
\end{tabular}

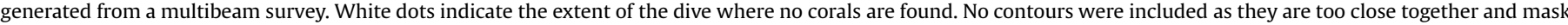
the coral occurrence. For finer scale along track data on coral distributions see Supplementary Figs. 1-4.

Table 1

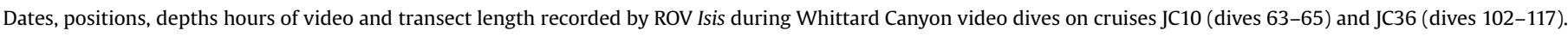

in 28 samples for $200 \mathrm{~m}$ depth bands, 17 samples for $500 \mathrm{~m}$ depth bands, and 17 samples for substratum type, to be used for timenormalised statistical analyses.

\subsection{Data analyses}

\subsubsection{Map creation}

All data were collated and formatted for compatibility with ESRI ArcGIS. A single bathymetric chart was created using EM120 swath mapping data collected during a previous cruise (JC35). Once video analysis was complete, latitudes and longitudes were assigned to each observation by identifying the time of observation in the Isis data string. Depth was also obtained in this manner. A map showing abundance of corals per $100 \mathrm{~m}$ along a transect was created by calculating the distances between observations. This ensured that all observation of corals could be visualised and overall occurrence patterns assessed, which would not have been possible with the time-normalised data.

A graduated colour scheme was applied to allow the difference in coral density to be visualised with five categories being chosen from 1-855 with high density of corals (233-855) being binned into one grade (Fig. 3). Substratum type was also plotted as a layer on this map for Dive 65, Dive 106, Dive 114 and Dive 116 to allow an indepth view of the relationship between substratum and the genera Acanella, Anthomastus and Lophelia (Supplementary Figs. 1-4). Again a graduated colour scheme was applied for the substratum type and individual genera per dive diving each genera into 5 categories.

\subsubsection{Multivariate analysis}

Multivariate analyses were carried out with PRIMER v6 to assess if coral assemblages change dependent on depth or substratum type. A 

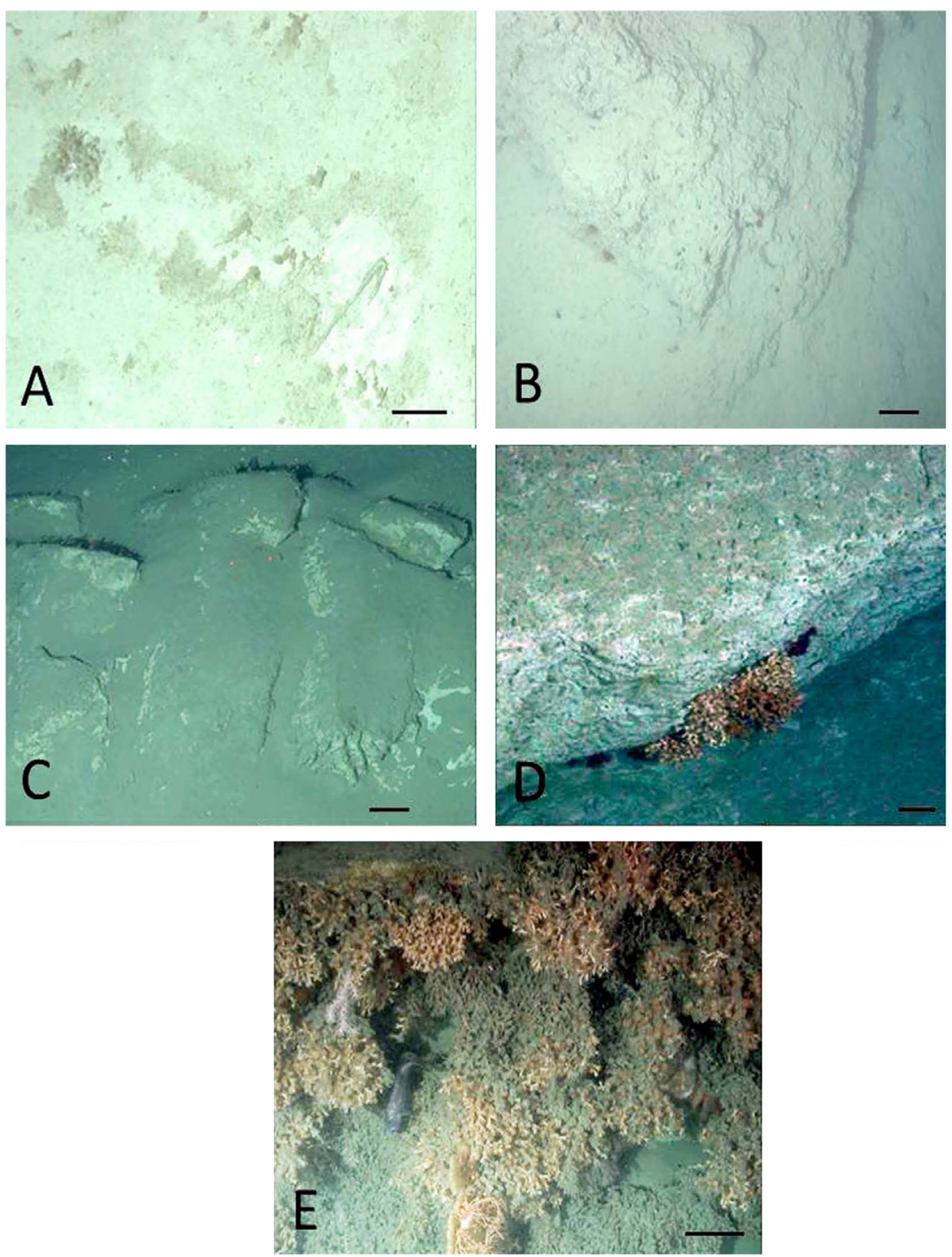

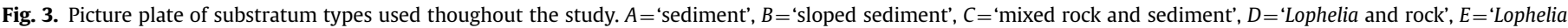
reef. Scale bar represent $10 \mathrm{~cm}$.

fourth-root transformation was used to reduce the effect of the dominant coral types on the faunal abundance data analyses (Clarke and Warwick, 1994) allowing SIMPER (Similarity Percentage analysis) to be employed to investigate which coral types were responsible for the changes in assemblage structure between variables. A Bray-Curtis coefficients were calculated allowing the use of ANOSIM (Analysis of Similarity) to analyse both depth and substratum type using the time-normalised data. Multi-dimensional scaling (MDS) was used to provide a visual representation of the data. MDS ordinates were plotted against substratum type.

\section{Results}

\subsection{Distribution and abundances of coral}

Thirteen usable dives were completed within the Whittard Canyon during the two RRS James Cook cruises JC10 and JC36 in 2007 and 2009, respectively (Table 1). Thirty-one putative types of coral (Table 2, Fig. 4) were recognised among 10,353 individuals. It was not always possible to distinguish either whip coral species or some pennatulid species in the videos and thus individuals within these taxa were grouped under the headings 'whip coral', 'pink whip coral' and 'Pennatulacea'. Of the 31 assigned coral types, three were responsible for $74.4 \%$ of all individuals: Acanella, Anthomastus and Lophelia. The greatest number per100 $\mathrm{m}$ transect length (855 individuals) occurred during Dive JC36-116 along a 'Lophelia reef' wall, where there was a steep overhang (Fig. 3). The areas with the greatest number of individuals occurred in the upper canyon where the slopes were at their steepest. Most areas were either devoid of coral or had only between 1 and 56 individuals per $100 \mathrm{~m}$ transect (Fig. 3).

Maps were created to compare the distributions of the dominant taxa with the occurrence of the different substratum types along four different dive tracks (Dive 65, Dive 106, Dive 114 and Dive 116). These dives included all the substratum types encountered in the study (Supplementary Figs. 1-4). The maps illustrate that the greatest numbers of Acanella coincided with areas of 'Mixed Sediment and Rock' and 'Sediment Slope' substratum types. Anthomastus was mainly associated with 'Sediment Slope'. 
Table 2


JC10 (Dives 63-65) and JC36 (Dives 102-117). Each + sign indicates the presence of a taxon within a given dive.

\begin{tabular}{|c|c|c|c|c|c|c|c|c|c|c|c|c|c|}
\hline & 63 & 64 & 65 & 102 & 105 & 106 & 107 & 109 & 113 & 114 & 115 & 116 & 117 \\
\hline \multicolumn{14}{|l|}{ Subclass: Hexacorallia } \\
\hline \multicolumn{14}{|l|}{ Order Antipatharia } \\
\hline \multicolumn{14}{|l|}{ Family Schizopathidae } \\
\hline Bathypathes sp. & + & & + & & & & & & & & & & \\
\hline \multicolumn{14}{|l|}{ Order Scleractinia } \\
\hline \multicolumn{14}{|l|}{ Family Caryophylliidae } \\
\hline Lophelia sp. & & & + & & & & & + & & + & + & + & + \\
\hline Madrepora sp. & & & + & & & & & & & + & & & \\
\hline Desmophyllum sp. & & & & & & & & + & & + & & + & + \\
\hline \multicolumn{14}{|l|}{ Subclass: Hydroidolina } \\
\hline \multicolumn{14}{|l|}{ Order Anthoathecatae } \\
\hline \multicolumn{14}{|l|}{ Family Stylasteridae } \\
\hline Stylasterid sp & & & + & & & & & & & & & & \\
\hline \multicolumn{14}{|l|}{ Subclass: Octocorallia } \\
\hline \multicolumn{14}{|l|}{ Order Gorgonacea } \\
\hline Red gorgonian & & & & & & & & & & & & + & \\
\hline \multicolumn{14}{|l|}{ Whip coral } \\
\hline Whip & + & & + & & & + & + & & + & + & & & \\
\hline Pink whip & & + & & & & & & & + & + & & & + \\
\hline \multicolumn{14}{|l|}{ Sub-Order Alcyoniina } \\
\hline Family Alcyoniidae & & & & & & & & & & & & & \\
\hline Anthomastus sp. & & + & + & + & + & + & & + & + & + & + & + & + \\
\hline Sub-Order Scleraxonia & & & & & & & & & & & & & \\
\hline Family Paragorgiidae & & & & & & & & & & & & & \\
\hline Orange Paragorgia & & & & & & & & & & + & & & \\
\hline Pink Paragorgia & & & & & & & & + & & & & & \\
\hline Sub-Order Calcaxonia & & & & & & & & & & & & & \\
\hline Family Chrysogorgiidae & & & & & & & & & & & & & \\
\hline Radicipes & & & + & & + & + & & & + & + & & & + \\
\hline Family Isididae & & & & & & & & & & & & & \\
\hline Acanella cf arbuscula & + & + & + & + & + & + & + & + & + & + & + & + & + \\
\hline Brush Isididae (Sp A) & & & & & & & & & & + & & & \\
\hline Bamboo bush coral (Sp B) & & & + & & & & & & & & & & \\
\hline Candelabra Isididae (Sp C) & & & & & & & & & & & & + & + \\
\hline Pink Isididae (Sp D) & + & & + & & & & & & & & & + & \\
\hline Skeleton Isididae (Sp E) & & & + & & & & & & & + & & & \\
\hline Whip Isididae (Sp F) & & + & + & + & & & & & & & & & \\
\hline Pink fan Isididae (Sp G) & & & + & & & & & & & & & + & \\
\hline Slender Pink Isididae (Sp H) & & & & & & & & & & & & + & \\
\hline Family Acanthogorgiidae & & & & & & & & & & & & & \\
\hline Acanthogorgia sp. & & & + & & & + & & + & + & + & + & + & + \\
\hline Family Primnoidae & & & & & & & & & & & & & \\
\hline Priminoa sp. & & & & & & & & + & & & & & \\
\hline Order Pennatulacea & & & & & & & & & & & & & \\
\hline Sub-Order Sessiliflorae & & & & & & & & & & & & & \\
\hline Family Kophoblemnidae & & & & & & & & & & & & & \\
\hline Kophobelemnon sp. & & & + & & & & & & & & & & \\
\hline Family Umbellulidae & & & & & & & & & & & & & \\
\hline Umbellula sp. & + & & + & & + & + & + & & + & + & + & + & \\
\hline Family Anthoptilidae & & & & & & & & & & & & & \\
\hline Anthoptilum sp. & & & + & & & + & + & + & & + & + & & + \\
\hline Family Protoptillidae & & & & & & & & & & & & & \\
\hline Distichoptilum gracile & & & + & & & + & & & & + & & & + \\
\hline Family Pennatulidae & & & & & & & & & & & & & \\
\hline Pennatula aculeata & & & + & & & & + & & & + & + & + & + \\
\hline Pennatulacea & + & & + & & & & + & & + & + & & & \\
\hline Unknown family & & & & & & & & & & & & & \\
\hline Purple coral & & & & & & & & & & + & & & \\
\hline Peach single polyp & & & & & & & & & & & + & + & \\
\hline
\end{tabular}

Lophelia formed reef structures and occurred in small patches in the 'Lophelia and rock' substratum. Acanella and Lophelia were not seen in the same region on any dive.

\subsection{Depth and distributions}

Multivariate analyses of coral community differences using timenormalised data binned into 200 and $500 \mathrm{~m}$ depth intervals revealed no obvious depth segregation (Supplementary Figs. 5 and 6). ANOSIM tests also indicated no significant differences in community composition ( $200 \mathrm{~m}$ bands $N=28, R=0.411, P=0.01 ; 500 \mathrm{~m}$ bands $N=17, R=0.033, P=0.36)$. As a result, depth was not considered as a co-variant in subsequent analyses.

\subsection{Overall distributions and substrata type}

Time-normalised data resulted in 17 samples where there was sufficient footage to allow analysis across the different substratum types (Supplementary Table 1). Within each 50 min observation period, the highest mean number of individuals occurred on 

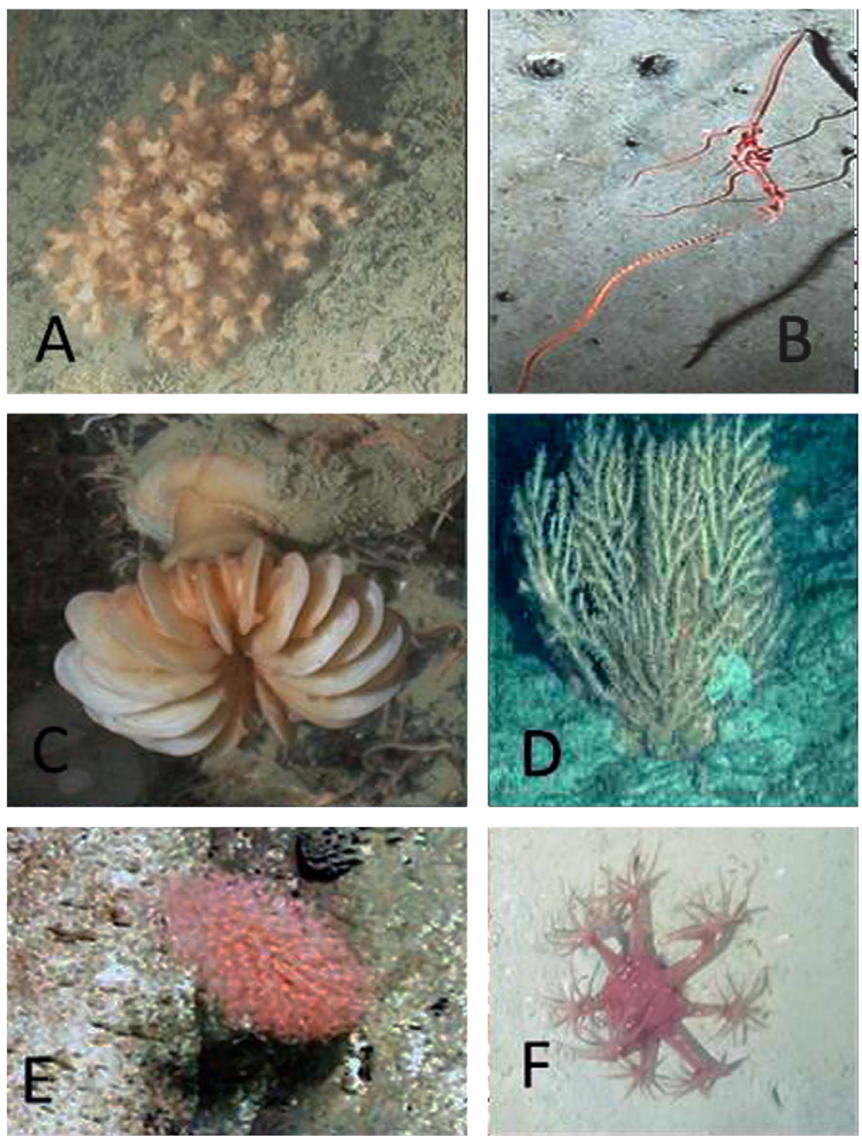

Fig. 4. Picture plate 1 of coral observed on video footage of the Whittard Canyon. (A) Lophelia pertusa $(\sim 30 \mathrm{~cm})$, (B) Distichoptilum gracile $(45 \mathrm{~cm})$, (C) Desmophyllum sp. $(\sim 10 \mathrm{~cm})$, ,(D) Primnoa sp. ( $60 \mathrm{~cm}),(\mathrm{E})$ Acanella sp. $(\sim 20 \mathrm{~cm}),(\mathrm{F})$ Anthomastus sp. $(\sim 15 \mathrm{~cm})$. Scale could not be included as a result of a lack of laser points within the pictures therefore rough estimations of size are given.

'Lophelia reef' with the lowest occurring on sediment (Fig. 5). This difference was not significant (Kruskal-Wallis, $D F=4, N=17$, $P=0.054)$. This is likely to be the result of the large standard errors indicating a large variation in the numbers observed within each substrata types on each dive (Fig. 5).

Individual substratum types are dominated by different taxa. 'Sediment' substratum contained the highest percentage of Isididae (Table 3). This was mainly attributed to large Acanella aggregations. Both 'Lophelia and rock' and 'Lophelia reef' had fewer coral higher taxa represented. 'Mixed Sediment and Rock' had a high occurrence of the alcyonarian Anthomastus and 94\% of the schizopathid Bathypathes were observed on the substratum. Pennatulacea were found within the 'Mixed Sediment and Rock' and 'Sediment' substrata. $100 \%$ of the Primnoidae occurred on the 'Mixed Sediment and Rock' substratum (Table 3).

Multi-dimensional scaling (MDS) (Fig. 6) illustrates a separation of the 'Lophelia reef' and 'Lophelia and rock' to the top left of the plot. 'Mixed Sediment and Rock' occurred in the centre with 'Sediment' and 'Sediment Slope' occurring close together. However, ANOSIM Global $\mathrm{R}(N=17, R=0.501, P=0.001)$ indicates no difference of the overall assemblage composition among substratum types (Table 4). Despite this, when pairs of substrata are considered, there are significant differences at the 5\% level between both 'Lophelia reef and 'Lophelia and rock' substrata and both the 'Mixed Sediment and Rock' and 'Sediment' substrata (Table 4). This indicates that the Lophelia substratum types are mainly responsible for the differences observed among

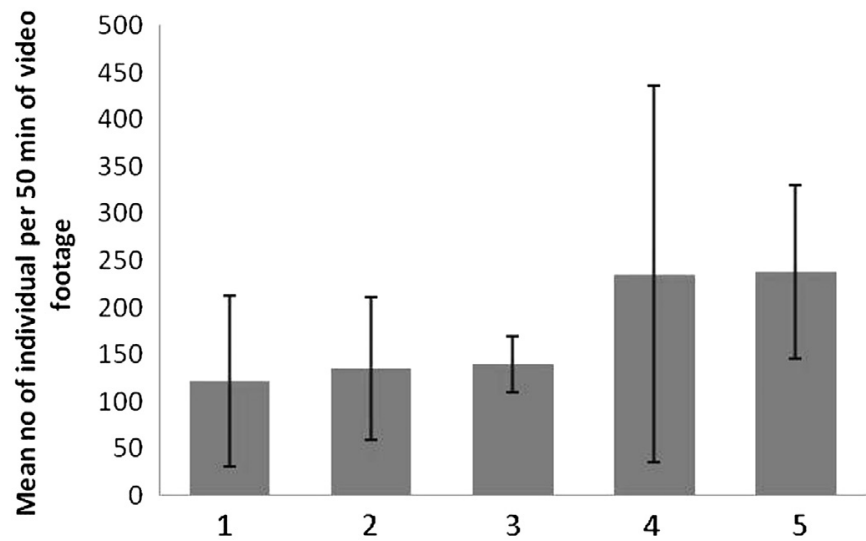

Fig. 5. Average number of individuals observed within a 50 min period on different substrata types with the Whittard Canyon. Each 50-min period is made up of ten 5-min segments accumulated together. Error bars indicate standard error from the mean. $N=17.1$ ='sediment', $2=$ 'sloped sediment', $3=$ 'mixed rock and sediment, $4=$ 'Lophelia and rock', $5=$ 'Lophelia reef'

Table 3

Coral taxon occurrence expressed as a \% of the total number of coral colonies observed per substratum type. Each row totals $100 \%$.

\begin{tabular}{lcclll}
\hline & Sediment & $\begin{array}{l}\text { Sediment } \\
\text { slope }\end{array}$ & $\begin{array}{l}\text { Mixed rock } \\
\text { and } \\
\text { sediment }\end{array}$ & $\begin{array}{l}\text { 'Rock } \\
\text { with } \\
\text { Lophelia' }\end{array}$ & $\begin{array}{l}\text { 'Lophelia } \\
\text { reef' }\end{array}$ \\
\hline Schizopathidae & 0 & 5.6 & 94.4 & 0 & 0 \\
Carophyliidae & 0 & 0 & 1.7 & 39.7 & 58.6 \\
Gorgonacea sp. & 0 & 0 & 0 & 0 & 100 \\
Whip coral & 8.6 & 5.8 & 80.8 & 2.9 & 1.9 \\
Alcyoniidae & 3.1 & 32.6 & 63.9 & 0.3 & 0 \\
Paragorgiidae & 0 & 0 & 50 & 50 & 0 \\
Chrysogorgiidae & 8.2 & 90.2 & 1.6 & 0 & 0 \\
Isididae & 55.9 & 13.1 & 27.2 & 0.3 & 3.4 \\
Primnoidae & 0 & 0 & 100 & 0 & 0 \\
Stylasteridae & 0 & 0 & 100 & 0 & 0 \\
Pennatulacea & 39.7 & 2.6 & 57.6 & 0 & 0 \\
Unknown & 2.5 & 2.5 & 75 & 20 & 0 \\
\hline
\end{tabular}

assemblages. By plotting the MDS X ordinate against substratum type it is possible to visualise a change in the assemblage structure with an increase in habitat complexity and hard substratum (Fig. 7). SIMPER tests indicate Lophelia, Acanella and Anthomastus are important in the determination of the assemblage composition, accounting for the majority of dissimilarity between communities (Table 5).

\section{Discussion}

The present study shows differences in community structure depending on the substratum type.

Large patches of Acanella observed throughout this study resulted in Isididae dominating coral communities in the 'Sediment' substratum, e.g Dive 114 (Supplementary Fig. 3). This is consistent with Mortensen et al. (2008) who found that Acanella dominated some sediment areas along the Mid-Atlantic Ridge (MAR). Species from the family Isididae have a root-like system which allows them to colonise and survive in sedimented areas (Gass and Willison, 2005; Woodby et al., 2009). This system is analogous to the peduncle in pennatulids which typically allows pennatulids to dominate coral communities in sedimented areas as shown at $450 \mathrm{~N}$ on the MAR (Morris et al., 2012). Chrysogorgidae also colonise areas of sediment (Mortensen and 


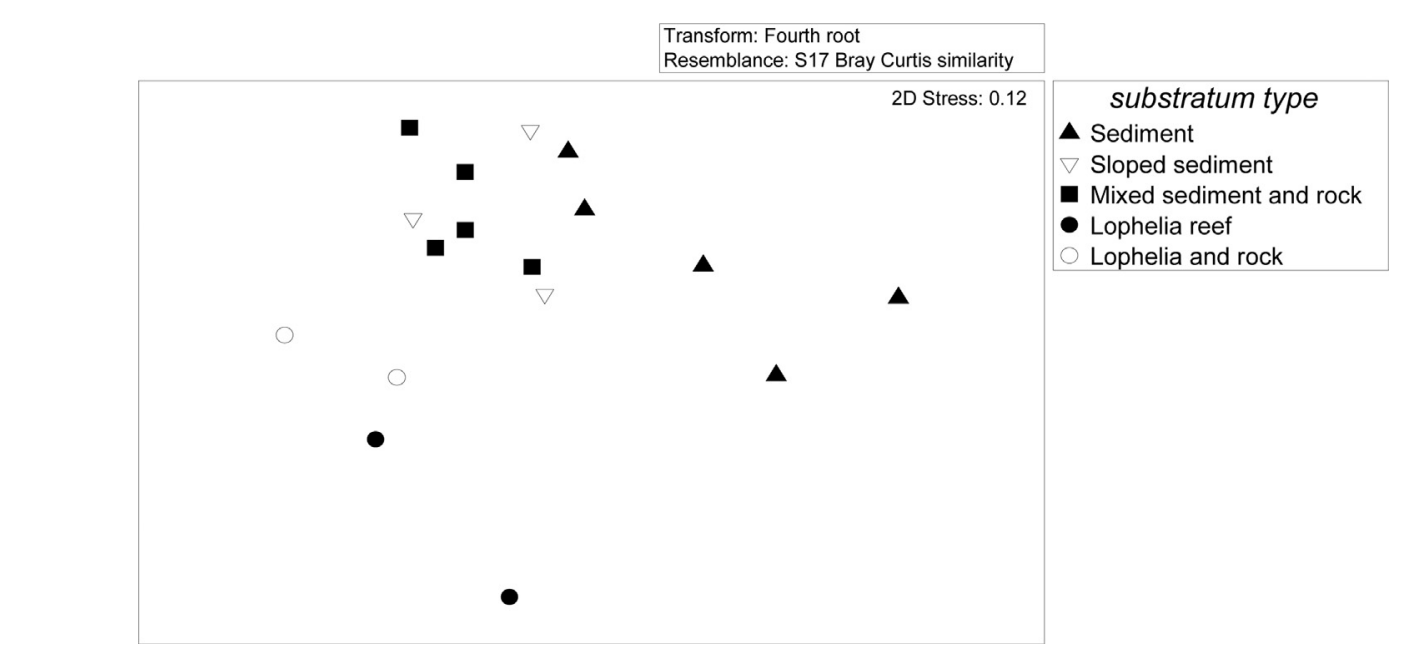

Fig. 6. Multi-dimension scaling ordination of coral assemblages structure from different substrata types across the Whittard Canyon dives.

Table 4

Results of ANOSIM tests comparing coral assemblages composition upon different substrata across Whittard Canyon Dives. $N=17$.

\begin{tabular}{|c|c|c|c|c|}
\hline $\begin{array}{l}\text { Global } R=\mathbf{0 . 1 0 2} \text {, } \\
P=\mathbf{0 . 1 3}\end{array}$ & $\begin{array}{l}\text { 'Sediment } \\
\text { Slope' }\end{array}$ & $\begin{array}{l}\text { 'Mixed Sediment } \\
\text { and Rock' }\end{array}$ & $\begin{array}{l}\text { 'Lophelia } \\
\text { reef' }\end{array}$ & $\begin{array}{l}\text { 'Lophelia } \\
\text { and Rock' }\end{array}$ \\
\hline \multirow[t]{2}{*}{ 'Sediment' } & $R=0.138$ & $R=0.468$ & $R=\mathbf{0 . 8 3 6}$ & $\boldsymbol{R}=\mathbf{0 . 7 0 9}$ \\
\hline & $P=0.26$ & $P=0.02$ & $P=0.04$ & $P=0.04$ \\
\hline \multirow[t]{2}{*}{ 'Sediment Slope' } & & $R=0.231$ & $R=1$ & $R=\mathbf{0 . 8 3 3}$ \\
\hline & & $P=0.16$ & $P=0.1$ & $P=0.1$ \\
\hline \multirow{4}{*}{$\begin{array}{l}\text { 'Mixed Sediment } \\
\text { and Rock' } \\
\text { 'Lophelia reef' }\end{array}$} & & & $R=0.945$ & $R=0.836$ \\
\hline & & & $P=0.04$ & $P=0.04$ \\
\hline & & & & $R=0.5$ \\
\hline & & & & $P=0.33$ \\
\hline
\end{tabular}

$R$ levels below 0.4 considered to have no difference.

$R$ levels $>0.4$ and $<0.7$ considered to be the same as they are different.

$R$ levels $>0.7$ considered different.

$P$ values $<0.05$ considered significant at $5 \%$ level.

$P$ Values $<0.1$ considered significant at $10 \%$ level (indicated in bold).

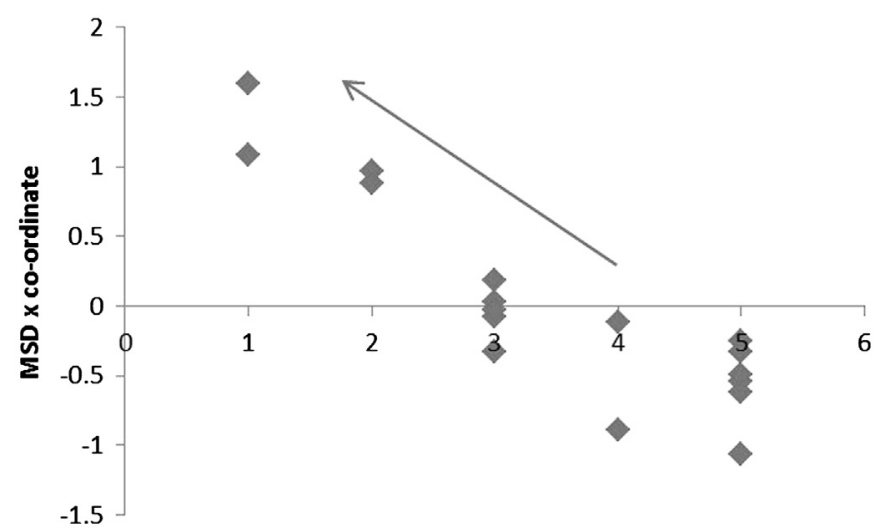

Fig. 7. Multi-dimension scaling $\mathrm{x}$ ordinate of coral assemblages against substrata type in the Whittard Canyon. 1="Lophelia reef", 2 ="Lophelia and rock", $3=$ "mixed rock and sediment', $4=$ 'sloped sediment', $5=$ ='sediment'.

Buhl-Mortensen, 2004; Woodby et al., 2009; Morris et al., 2012). In the Whittard Canyon Chrysogorgidae were prevalent in the 'Sediment Slope' substratum (Table 3), with fewer individuals in flat 'Sediment' areas. Anthomastus was also a key coral taxon in areas of sedimented slope (Supplementary Figs. 1-4). However, a difference in mean number of individuals observed per time period was
Table 5

Results of SIMPER tests comparing significantly different coral assemblage compositions relative to different substrata in the Whittard Canyon. Number represents the percentage of dissimilarity between the two substrata types. The three most important taxa contributing to the dissimilarity are listed in each case.

\begin{tabular}{lll}
\hline & 'Lophelia reef' & 'Lophelia and Rock' \\
\hline \multirow{2}{*}{ 'Sediment' } & $92.0 \%$ & $88.98 \%$ \\
& Lophelia & Lophelia \\
& Acanella & Primnoa \\
& Pennatula aculeata & Anthomastus \\
& $88.98 \%$ & $75.88 \%$ \\
& Lophelia & Acanella \\
& Acanella & Lophelia \\
& Acanothogorgia & Primnoa \\
'Mixed Sediment and Rock' & $86.12 \%$ & $67.19 \%$ \\
& Lophelia & Acanella \\
& Anthomastus & Lophelia \\
& Acanella & Primnoa \\
\hline
\end{tabular}

not discernible between 'Sediment Slope' and 'Sediment' (Fig. 5). It is likely that most of the 'Sediment Slope' areas are rock draped in sediment. Such structures are prone to periodic slump events which could wipe out the coral assemblages present and lead to a reduced density than would otherwise be observed (Okey, 1997). A sediment drape may indicate that despite the Whittard Canyon being an active canyon system, current flows are reduced in at least some areas, preventing erosion of the sediment and promoting the development of 'Sediment' coral taxa, such as Acanella. This would indicate that there are complex interactions of factors other than the steepness of the slope, which has been believed to lead to an enhanced abundance of fauna as a result of changed oceanographic conditions (Genin et al., 1986, 1989).

Lophelia was generally observed on overhangs and on boulders surrounded by sediment. 'Lophelia reef and 'Lophelia and rock' substrata had the greatest densities of coral, although the coral distribution was extremely patchy (Fig. 5). In areas where Lophelia occurred in high abundance octocorals were less abundant and showed a reduced taxa richness (Table 3 ). This could indicate that although Lophelia increases regional diversity by providing a structural habitat for other organisms (Buhl-Mortensen and Mortensen, 2005; Clark et al., 2006), it could possibly be outcompeting other coral taxa within the North East Atlantic. Within this study Lophelia was found in dives with a depth range of $520-2448 \mathrm{~m}$ 
(Tables 1 and 2). The Aragonite Saturation Horizon (ASH) may limit the distribution of Lophelia (Turley et al., 2007). It occurs at a depth of about $2000 \mathrm{~m}$ within the Bay of Biscay (de Mol et al., 2011: Davies et al., 2008). Therefore the lower distribution limit of Lophelia in the Whittard Canyon ( $2448 \mathrm{~m}$ ) may be associated with the Aragonite Saturation Horizon. Clark et al. (2006) also found that the ASH was a major factor determining the distribution of scleractinian corals on seamounts. Below the ASH there have been reports of reduced abundance of Scleractinia (Roberts et al., 2009) with the possibility that other corals taxa fill the available niche. This would result in the increased taxon richness away from Lophelia areas observed in this study (Table 3). However, it has been found that there are areas where the substratum type present appears optimal for colonisation, yet no corals are present. This agrees with Mortensen and Buhl-Mortensen (2004) who found areas of cobble and boulder devoid of gorgonians, despite being within the optimal depth range. From this it can be suggested that factors other than substratum type and ASH, such as oceanographic regime and associated food availably, play an important role in small-scale coral distribution patterns within the canyon, producing a very heterogeneous and patchy environment for different coral taxa.

The deep sea is a food limited environment (Smith et al., 2009). Corals are passive suspension feeders and thus require a particle flux high enough to meet their metabolic needs, suggesting that not all areas are suitable for colonisation (Thistle, 2003). During cruise JC36 Stand Alone Pump Systems (SAPs) were used to measure the concentration of particles sinking to the sea floor within the canyon (Masson, 2009). Although particulate organic carbon (POC) is directly related to surface production, the preliminary results from the SAPs demonstrate that some areas within the canyon are subject to higher organic input than others. When the POC composition was analysed it was found that the eastern and western branch had different molecular signatures (Huvenne et al., 2011). Changes in the composition of POC input may influence the community structure of the Whittard Canyon, as seen, for instance, on the adjacent abyssal plain (Billett et al., 2001, 2010). Although very little work has been undertaken on cold-water coral lipid content, Hamoutene et al. (2008) found that there were differences in lipid content between species. Gorgonians were found to have lower lipid content than soft corals, seapens and Antipatharia (Hamoutene et al., 2008). Ancathogorgia armata has also been found to feed at a higher tropic level than Primnoa species (Sherwood et al., 2008). This indicates that different coral species thrive under different organic matter input conditions and that the composition, as well as freshness of the POC, has an impact on the coral assemblages.

The Whittard Canyon is a very active and open system, acting as a conduit of sediment into the deep sea (de Stigter et al., 2007; Arzola et al., 2008). It funnels organic matter to depth via a variety of mechanisms including tidal currents, internal waves and turbidity flows (Duineveld et al., 2001; Quaresma et al., 2007). The greater hydrodynamic activity in the canyon leads to an increase in organic matter input and increased food quality within the canyon in comparison to less active areas on the open continental slope. Kiriakoulakis et al. (2011) found that sediments in canyons on the Portuguese Margin are enriched in organic matter in comparison to slope sediments. Similarly, Rowe (1971) found increased sediment transport within canyons led to enhanced food availability at depth. This may account for the apparent lack of a significant effect of depth on the coral communities in the Whittard Canyon (Fig. 5), because greater food is available at all depths. On the open continental slope the sharp decrease in food with increasing depth leads to major changes in community structure. It is also possible that this is a result of the patchiness of the coral community and the relative small sample size attainable from the studies.

\section{Conclusion}

This study has shown that substratum type has an effect on the cold-water coral assemblages in the Whittard Canyon. Coral densities were greatest on 'Lophelia reef' and 'Lophelia and rock' substrata. However, the taxon richness of coral was reduced in areas with Lophelia, possibly because Lophelia out-competes other suspension feeding coral taxa. In this respect, although depth is not shown to have an effect on the assemblage structure per se in the Whittard Canyon, the loss of Lophelia with increasing depth, due in part to the Aragonite Saturation Horizon, may prevent Lophelia from dominating coral communities in deeper parts of the canyon. Substratum type, changed oceanographic regimes, topography, and the interaction of topography and physics produce a very heterogeneous and patchy environment for different coral taxa. These factors lead to enhanced POC inputs in the Whittard Canyon in leading to greater taxon richness and greater abundances than in other more nutrient poor areas.

\section{Acknowledgments}

We would like to thank the science team and crew of RRS James Cook cruise JC10 and JC36 for collecting the video. We would also like to thank Brian Bett for statistical advice. Funding for this project was provided by NERC studentship NE/F009097/1 to KM and the HERMES and HERMIONE project contract numbers GCECT_2005-511234 and 226354. Finally we would like to thank the two anonymous reviewers who took the time to read this manuscript and gave helpful advice and incites.

\section{Appendix A. Supplementary Information}

Supplementary data associated with this article can be found in the online version at http://dx.doi.org/10.1016/j.dsr2.2013.03.036.

\section{References}

Aminot, A., Kerouel, R., 2004. Dissolved organic carbon, nitrogen and phosphorus in the N-E Atlantic and the N-W Mediterranean with particular reference to nonrefractory fractions and degradation. Deep-Sea Res. I 51, 1975-1999.

Arhan, M., De Verdiere, A.C., Memery, L., 1994. The eastern boundary of the subtropical North Atlantic. J. Phys. Oceanogr. 24, 1295-1316.

Arzola, R.G., Wynn, R.B., Lastras, G., Masson, D.G., Weaver., P.P.E., 2008. Sedimentary features and processes in the Nazaré and Setubal submarine canyons, west Iberian margin. Mar. Geol. 250, 64-88.

Billett, D.S.M., Bett, B.J., Reid, W.D.K., Boorman, B., Priede, I.G., 2010. Long-term changes in the abyssal NE Atlantic: the 'Amperima Event' revisited. Deep-Sea Res. II 57, 1406-1417.

Billett, D.S.M., Bett, B.J., Rice, A.L., Thurston, M.H., Galéron, J., Sibuet, M., Wolff, G.A., 2001. Long-term change in the megabenthos of the Porcupine Abyssal Plain (NE Atlantic). Prog. Oceanogr. 50, 325-348.

Buhl-Mortensen, L., Mortensen, P.B., 2005. Distribution and diversity of species associated with deep-sea gorgonian corals off Atlantic Canada. In: Freiwald, A., Roberts, J.M. (Eds.), Cold-Water Corals and Ecosystems. Springer, Berlin Heidelberg, New York, pp. 849-879.

Cairns, S.D., 2007. Deep-water corals; an overview with special reference to diversity and distribution of deep-water scleractinian corals. Bull. Mar. Sci. $81,311-322$

Clark, M.R., Tittensor, D., Rogers, A.D., Brewin, P., Schlacher, T., Rowden, A., Stocks, K., Consalvey, M., 2006. Seamounts, Deep-Sea Corals and Fisheries: Vulnerability of Deep-Sea Corals to Fishing on Seamounts Beyond Areas of National Jurisdiction UNEP-WCMC, Cambridge, UK, 80 pp.

Clarke, K.R., Warwick, R.M., 1994. Changes in Marine Communities: An Approach to Statistical Analysis and Interpretation. Plymouth Marine Laboratory, UK.

Davies, J., Guinan, J., Howell, K., Stewart, H., Verling, E., 2008. MESH South West Approaches Canyons Survey (MESH Cruise 01-07-01) Final Report. MESH Partnership.

Duineveld, G., Lavaleye, M., Berghuis, E., de Wilde, P., 2001. Activity and composition of the benthic fauna in the Whittard Canyon and the adjacent continental slope (NE Atlantic). Oceanol. Acta 24, 69-83. 
Garcia, R., van Oevelen, D., Soetaert, K., Thomsen, L., de Stigter, H.C., Epping, E., 2008. Deposition rates, mixing intensity and organic content in two contrasting submarine canyons. Prog. Oceanogr. 76, 192-215.

Gass, S.E., Willison, M.J.H., 2005. An assessment of the distribution of deep-sea corals in Atlantic Canada by using both scientific and local forms of knowledge. In: Freiwald, A., Roberts, J.M. (Eds.), Cold-Water Corals and Ecosystems. Springer, Berlin Heidelberg, New York, pp. 223-245.

Genin, A., Dayton, P.K., Lonsdale, P.F., Spiess, F.N., 1986. Corals on seamount peaks provide evidence of current acceleration over deep-sea topography. Nature 322, 59-61.

Genin, A., Nobel, M., Lonsdale, P.F., 1989. Tidal currents and anticyclonic motions on two North Pacific seamounts. Deep-Sea Res. I 36, 1803-1815.

Harris, P.T., Whiteway, T., 2011. Global distribution of large submarine canyons: geomorphic differences between active and passive continental margins. Mar. Geol. 285, 69-86.

Hamoutene, D., Puestow, T., Miller-Banoub, J., Wareham, V., 2008. Main lipid classes in some species of deep-sea corals in the Newfoundland and Labrador region (Northwest Atlantic Ocean). Coral Reefs 27, 237-246.

Huvenne, V.A.I., Tyler, P.A., Masson, D.G., Fisher, E.H., Hauton, C., Huhnerbach, V., Le Bas, T.P., Wolff, G., 2011. A picture on the wall: innovative mapping reveals coldwater coral refuge in submarine canyon. PLoS One 6, e28755, http://dx.doi.org/ 10.1371 /journal.pone.0028755.

Kiriakoulakis, K., Blackbird, S., Ingels, J., Vanreusel, A., Wolff, G.A., 2011. Organic geochemistry of submarine canyons: the Portuguese Margin. Deep-Sea Res. II 58, 2477-2488.

Lindner, A., Cairns, S.D., Cunningham, C.W., 2008. From offshore to onshore: multiple origins of shallow-water corals from deep-sea ancestors. PLoS One 3, e2429, doi: 2410.1371/journal.pone.0002429.

Masson, D.E., 2009. RRS James Cook Cruise 36, 19 Jul-28 Jul 2009. The Geobiology of Whittard Submarine Canyon. National Oceanography Centre, Southampton, UK, 53 pp (National Oceanography Centre Southampton Cruise Report No. 41).

Matthias, T., Godfrey, J.S., 2003. Chapter 15: Hydrology of Atlantic Ocean Regional Oceanography: An Introduction. Daya Publishing House, Delhi, pp. 254-270.

Morris, K.J., Tyler, P.A., Murton, B., Rogers, A.D., 2012. Lower bathyal and abyssal distribution of coral in the axial volcanic ridge of the Mid-Atlantic Ridge at $45^{\circ}$ N. Deep-Sea Res. I 62, 32-39.

Mortensen, P.B., Buhl-Mortensen, L., 2004. Distribution of deep-water gorgonian corals in relation to benthic habitat features in the Northeast Channel (Atlantic Canada). Mar. Biol. 144, 1223-1238.

Mortensen, P.B., Buhl-Mortensen, L., Gebruk, A.V., Krylova, E.M., 2008. Occurrence of deep-water corals on the Mid-Atlantic Ridge based on MAR-ECO data. DeepSea Res. II 55, 142-152.

Okey, T.A., 1997. Sediment flushing observations, earthquake slumping, and benthic community changes in Monterey Canyon head. Cont. Shelf Res. 17, 877-897.

Oliveria, A., Vitorino, J., Rodriques, A., Jouanneau, J.M., Dias, J.A., Weber, O., 2002 Nepheloid layer dynamics on the Nazaré canyon System and adjacent shelf (Portugal). Prog. Oceanogr. 52, 195-213.

Quaresma, L.S., Vitorino, J., Oliveira, A., da Silva, J., 2007. Evidence of sediment resuspension in nonlinear internal waves on the western Portuguese mid-shelf. Mar. Geol. 246, 123-143.
Reid, G.S., Hamilton, D., 1990. A reconnaissance survey of the Whittard Sea Fan, Southwestern approaches, British Isles. Mar. Geol. 92, 69-86.

Roberts, J.M., Wheeler, A.J., Freiwald, A., Cairns, S., 2009. Cold-Water Corals: The Biology and Geology of Deep-Sea Coral Habitats. Cambridge University Press, Cambridge.

Rowe, G.T., 1971. The exploration of submarine canyons and their benthic faunal assemblages. Proc. R. Soc. Edin. (B), 159-16917, 159-169.

Sherwood, O.A., Jamieson, R.E., Edinger, E.N., Wareham, V.E., 2008. Stable C and N isotopic composition of cold-water corals from the Newfoundland and Labrador continental slope: examination of trophic, depth and spatial effects. DeepSea Res. I 55, 1392-1402.

Smith, K.L., Ruhl, H.A., Bett, B.J., Billett, D.S.M., Lampitt, R.S., Kaufmann, R.S., 2009 Climate, carbon cycling and deep-ocean ecosystems. Proc. Natl. Acad. Sci. USA 106, 19211-19218.

Thistle, D. 2003. The deep-sea floor: an overview. In: Tyler, P.A. (Ed.), Ecosystems of the World Vol 28. Ecosystems of the Deep Oceans. Elsevier, Amsterdam, pp. 5-37.

Turley, C.M., Roberts, J.M., Guinotte, J.M., 2007. Corals in deep-water: will the unseen hand of ocean acidification destroy cold-water ecosystems? Coral Reefs 26, 445-448, http://dx.doi.org/10.1007/s00338-007-0247-5.

Vetter, E.W., Smith., C.R., De Leo, F.C., 2010. Hawaiian hotspots: enhanced megafaunal abundance and diversity in submarine canyons on the oceanic island of Hawaii. Mar. Ecol. 31, 183-199.

Vangrieshem, A., 1985. Hydrologie et circulation profonde. In: Laubier, L., Monniot C. (Eds.), Peuplements Profonds du Golfe de Gascogne: Campagne BIOGAS IFREMER. pp. 43-70.

Wall, D., Tregenza, N., De Stinger, H., 2010. Exploring the feasibility of static acoustic monitoring for deep diving whales. 〈http://www.iwdg.ie/downloads/ecs08poster pdf>.

Watanabe, S., Metaxas, A., Sameoto, J., Lawton, P., 2009. Patterns in abundance and size of two deep-water gorgonian octocorals, in relation to depth and substrate features off Nova Scotia. Deep-Sea Res. I 56, 2235-2248.

Weaver, P.P.E., Masson, D., 2007. RRS James Cook Cruise 10, 13 May-07 Jul 2007. Hotspot ecosystems in the NE Atlantic. UK contribution to the HERMES Project Mud volcanoes in the Gulf of Cadiz Submarine canyons west of Portugal Submarine canyons in the northern Bay of Biscay Southampton, UK: National Oceanography Centre, Southampton, 93 pp (National Oceanography Centre Southampton Cruise Report No. 22)

Woodby, D., Carlile, D., Hulbert, L., 2009. Predictive modelling of coral distribution in the Central Aleutian Islands, USA. Mar. Ecol. Prog. Ser. 397, 227-240.

de Leo, F.C., Smith, C.R., Rowden, A.A., Bowden, D.A., Clark, M.R., 2010. Submarine canyons: hotspots of benthic biomass and productivity in the deep sea. Proc. $\mathrm{R}$. Soc. B 277, 2783-2792

de Mol, L., Van Rooij, A., Pirlet, H., Greinert, J., Frank, N., Quinnerais, F., Henriet, J., 2011. Cold-water coral habitats in the Penmarc'h and Guilvinec Canyons (Bay of Biscay): deep-water versus shallow-water settings. Mar. Geol. 282, $40-52$.

de Stigter, H.C., Boer, W., De Jesus Mendes, P.A, Jesus, C.C. Thomsen, L, van den Bergh, G.D., van Weering, T.C.E., 2007. Recent sediment transport and deposition in the Nazaré Canyon, Portuguese continental margin. Mar. Geol. 246, 144-164. 